\title{
Soybean diseases in Poland
}

\section{J. MARCINKOWSKA, J. W. TOMALA-BEDNAREK, M. SCHOLLENBERGER}

Institute of Plant Protection, Warsaw Agricultural University, Nowoursynowska 166, 02-766

Warszawa, Poland

(Received: December 19, 1980)

\begin{abstract}
Field observations on the occurrence of soybean diseases were undertaken in the southern and central regions of Poland in the period 1976-1980. Most prevalent were foliage diseases caused by Peronospora manshurica, Pseudomonas syringae pv. glycinea and soybean mosaic virus (SMV). Sclerotinia sclerotiorum and Ascochyta sojaecola were reported as pathogens of local importance. The following pathogenic fungi: Botrytis cinerea, Fusarium culmorum, $F$. oxysporum and Rhizoctonia solani were also isolated from soybean.
\end{abstract}

\section{INTRODUCTION}

Fungi are the most numerous soybean pathogens 〈Sinclair and Shurtleff, 1975〉. Among them Peronospora manshurica〈Naum. Syd. et Gaum. is of an economic importance in some cultivation regions. Downy mildew caused by this fungus has been reported from Romania $\langle R$ osca, 1975〉, Yugoslavia 〈Acimovic, 1976〉 and North America $\langle$ Hildebrand and K och, 1951; D u n le a vy, 1971 $\rangle$. The pathogens which might be of great local importance were Sclerotinia sclerotiorum $\langle$ Lib. $\rangle$ de Bary and Ascochyta sojaecola Abramov. Sclerotinia stem rot occurred often in Romania $\langle\mathrm{H} \mathrm{u} \mathrm{le} \mathrm{a} \mathrm{et} \mathrm{al.,} \mathrm{1973〉}$ and France $\langle$ Sign oret et al., 1976〉 while ascochyta blight was commonly noted in Germany $\langle$ Frandsen, 1953〉 and Hungary $\langle$ T oth and Kovics, 1978>.

The bacterium Pseudomonas syringae pv. glycinea 〈Coerper> Young, Dye and Wilkie causing bacterial blight of soybean was observed quite often in the north regions of the United States $\langle\mathrm{D}$ a f t and Le be n, 1972〉, Soviet Union $\langle$ Klyk ov, 1963〉, France $\langle$ Signoret et al., 1976〉 and Austria $\langle\mathrm{Zwatz}$, $1979\rangle$.

Of several soybeañ virus diseases which have been reported $\langle\mathrm{M} u$ r a v' e va, 1968; Sinclair and Shurtleff, 1975>, soybean mosaic caused by soybean 
mosaic virus 〈SMV > occurs most often and is of the greatest economic importance. Symptoms of this disease were described by many investigators $\langle$ Gardner and Kendrick, 1921; Sinclair and Shurtleff, 1975〉.

Soybean is a new crop in Poland which has been recently introduced for cultivation by plant breeders. The objective of this observation was to determine the soybean pathogens in our country as well as the severity of the occurring diseases.

\section{MATERIAL AND METHODS}

Field observations on disease occurrence were done on 2-3-week-old seedlings and on plants in stages of blooming and pod formation. Records were made when the symptoms were most pronounced at the time of the highest pathogens population development. Occurrence of soybean diseases on experimental plots and on production fields was estimated in the south-east $<$ districts of Zamość, Rzeszów, Przemyśl, Tarnobrzeg〉, south-west 〈districts of Opole, Wroclaw > and in central Poland 〈district of Warsaw.

Pathogens were identified in the fields on the basis of disease symptoms. A more detailed description was prepared in the laboratory. Fungi were identified by considering the structure of the mycelium and their sporulation $<$ the following keys were used: A bra mov, 1931; A rx von, 1974; B o ot h, 1971; Gä u man n, 1923, Purd y, 1955>.

Bacteria were identified by the following tests: Gram stain, growth on Kado's D 4 medium for Pseudomonas spp. 〈K a d o and $\mathrm{Hesket} \mathrm{t,} \mathrm{1970 \rangle ,} \mathrm{fluorescein}$ production on King B agar, levan formation, hypersensitive reaction on tobacco $\langle$ Lelliot t et al., 1966〉.

The virus was identified on the basis of symptoms which occurred on soybeans, the reaction of indicator host plants, host range and physical properties. Chenopodium quinoa and Chenopodium album were used as indicator host plants. Biological tests were carried out in the greenhouse by mechanical sap inoculations with the use of carborundum.

The pathogenicity of collected fungi, bacteria and virus isolates was confirmed in greenhouse tests.

The severity of downy mildew and bacterial blight was calculated according to the modified INTSOY disease index, as follows: 0 - no symptoms; 1 - a few small spots on about $5 \%$ of plants; 2 - a few spots on max. $25 \%$ of plants; $3-$ some small spots on all plants or more extensive merging lesions on about $50 \%$ of plants; 4 - numerous spots differing in size, coalescing, often necrotic on about $75 \%$ of plants; 5 - symptoms as in 4 but on all plants. The incidence of soybean mosaic in the field was given as per cent of infected plants. Plants showing typical symptoms of soybean mosaic were considered to be infected. 


\section{RESULTS}

Soybean seedling blight, so far, is of minor importance in Poland 〈Table 1〉. Among the causal agents more prevalent were Fusarium culmorum and Ascochyta sojaecola while Fusarium oxysporum and Rhizoctonia solani appeared quite seldom.

Table 1

Occurrence of soybean diseases in Poland

\begin{tabular}{lrrrr}
\hline \multirow{2}{*}{ Disease } & \multicolumn{4}{c}{ Year of observation } \\
\cline { 2 - 5 } & 1977 & 1978 & 1979 & 1980 \\
\hline Downy mildew & $8 / 15^{*}$ & $11 / 20$ & $11 / 20$ & $21 / 21$ \\
Ascochyta blight & $15 / 15$ & $18 / 20$ & $20 / 20$ & $21 / 21$ \\
Sclerotinia stem rot & $7 / 15$ & $6 / 20$ & $2 / 20$ & $3 / 21$ \\
Gray mold & $15 / 15$ & $6 / 20$ & $4 / 20$ & $0 / 21$ \\
Fusarium seedling blight & $0 / 15$ & $6 / 20$ & $0 / 20$ & $0 / 21$ \\
Rhizoctonia damping-off & $0 / 15$ & $3 / 20$ & $0 / 20$ & $0 / 21$ \\
Bacterial blight & $15 / 15$ & $16 / 20$ & $16 / 20$ & $20 / 21$ \\
Soybean mosaic & $15 / 15$ & $19 / 20$ & $20 / 20$ & $20 / 21$ \\
\hline
\end{tabular}

*8/15 disease was observed on 8 of 15 fields.

Some fungal diseases on older plants occurred commonly $\langle$ Table 1$\rangle$. Downy mildew caused by Peronospora manshurica appeared usually on soybean in the beginning of July. Further development and intensity of disease depended first of all on the air humidity in the consecutive years and in different locations <Table $2\rangle$. However, severe downy mildew development was usually observed in the last

Table 2

Soybean infection by Peronospora manshurica (A) and by Pseudomonas syringae pv. glycinea (B) in the period 1977-1980 (disedse rate 0-5)

\begin{tabular}{|c|c|c|c|c|c|c|c|}
\hline \multirow{2}{*}{$\begin{array}{l}\text { Location } \\
\text { and district }\end{array}$} & \multirow{2}{*}{ Year } & \multicolumn{3}{|c|}{ Varieties and line (A) } & \multicolumn{3}{|c|}{ Varieties and line (B) } \\
\hline & & Acme & Ajma & NM-4961 & Acme & Ajma & NM-4855 \\
\hline \multirow[t]{2}{*}{ Radzików } & 1977 & 3.5 & 1.0 & 3.25 & 2 & $\mathbf{1}$ & 4 \\
\hline & 1978 & 4.5 & 2.0 & 4.0 & 1.25 & $\mathbf{0}$ & 2.5 \\
\hline \multirow[t]{3}{*}{ Warsaw } & 1979 & 2.75 & 1.0 & 2.5 & 2.5 & 0.5 & 3 \\
\hline & 1980 & 3.75 & 1.0 & 2.75 & $\mathbf{3}$ & 2 & $\mathbf{3 . 2 5}$ \\
\hline & 1977 & - & 3.5 & 3.5 & - & 1.5 & 2.5 \\
\hline Przeclaw & 1978 & 3.0 & 1.25 & 3.5 & $\mathbf{3}$ & 2 & 3.5 \\
\hline \multirow[t]{3}{*}{ Rzeszów } & 1979 & 1.75 & 0.25 & 1.0 & 1.75 & 0.75 & 2 \\
\hline & 1980 & 3.5 & 1.75 & 2.75 & 2.25 & 1.5 & $\mathbf{3}$ \\
\hline & 1977 & $\mathbf{3 . 3}$ & $\mathbf{0}$ & 4.3 & 2.3 & 0.7 & 4.3 \\
\hline Jankowice & 1978 & 2.5 & 0.25 & 3.0 & 3.75 & 1.25 & 3.75 \\
\hline \multirow[t]{2}{*}{ Przemysl } & 1979 & 2.0 & 0.75 & 1.5 & 2.25 & 1.25 & 3 \\
\hline & 1980 & 3.25 & 2.25 & 3.0 & 1.5 & 1 & 2.75 \\
\hline
\end{tabular}


ten days of August during cool nights accompanied by a longlasting dew on the foliage. In circumstances of high disease severity numerous, pale green spots of secondary infection were produced on the leaves next to brown necrotic lesions. On the lower leaf surface spots were covered with grayish conidiophores $\langle$ Figs. 1, 2). On soybean seeds mycelium and oospores of Peronospora manshurica were noted.
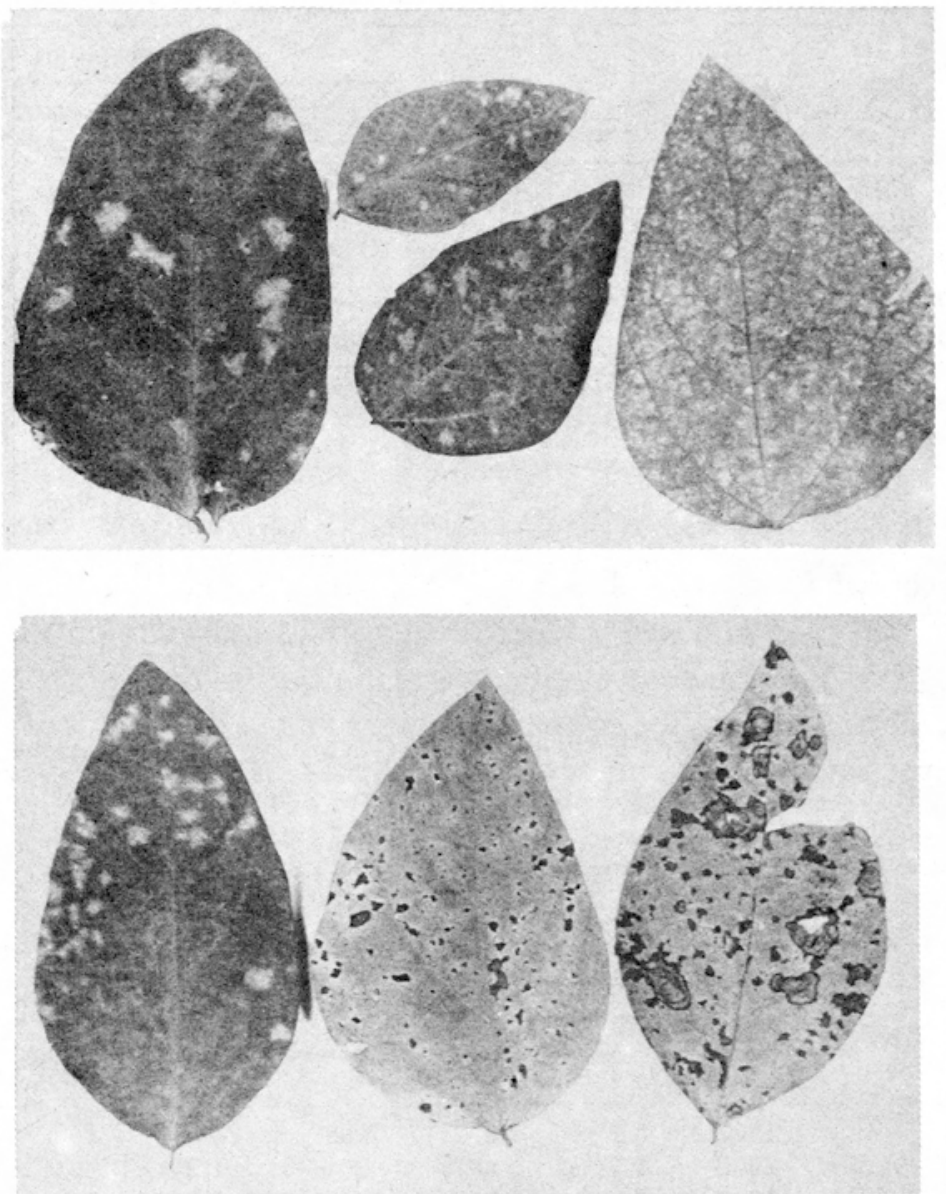

Fig. 1,2. Diversity of downy mildew symptoms on the soybean leaves

Ascochyta sojaecola could affect leaves, petioles, stems and pods of soybean. Spots on leaves appeared first on the lower part of the plant where the fungus had favourable humidity conditions for infections $<$ Fig. $3>$. On young leaves single, round, brown, often with darker margin spots were produced. On older yellowish leaves spots were more numerous. Symptoms on stems occurred as brown 
elongated streaks. The lesions were covered later with dark pycnidia of the causal fungus. Symptoms of ascochyta blight on pods were diversified; from small spots to browning of intact poorly developed pods $\langle$ Fig. 4$\rangle$. Ascochyta blight disease developed best on plants from the midseason to maturity of the crop. At that time the disease could commonly occur 〈Table 1〉. As the consequence of stem branchings infection, dying of side stem was observed $\langle$ Fig. 5$\rangle$.

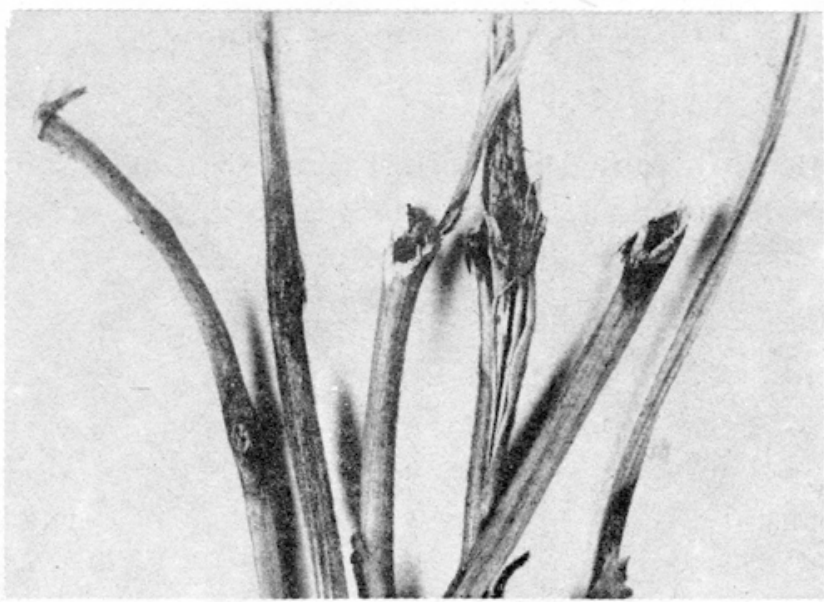

Fig. 3. Ascochyta blight on stem

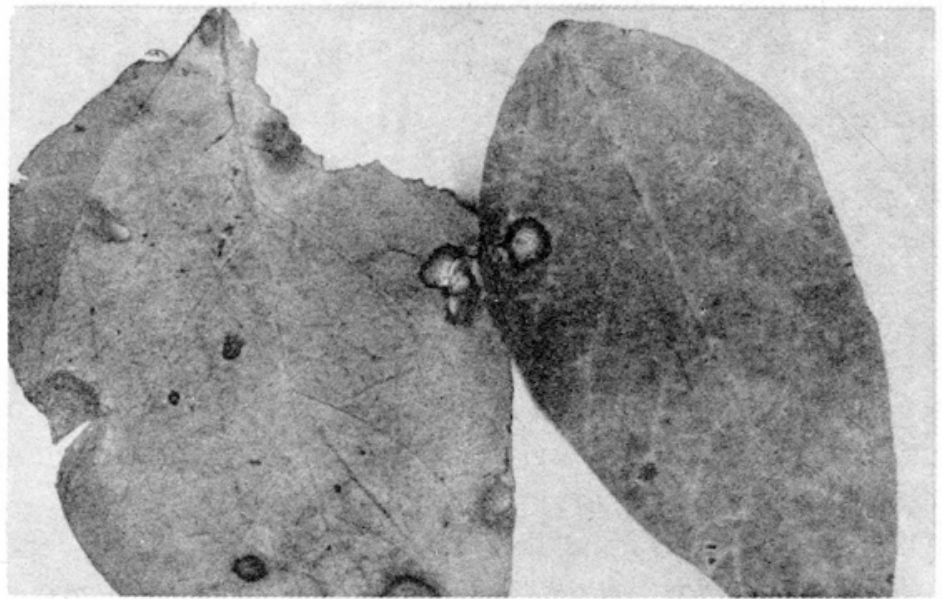

Fig. 4. Ascochyta spots on the soybean leaves 


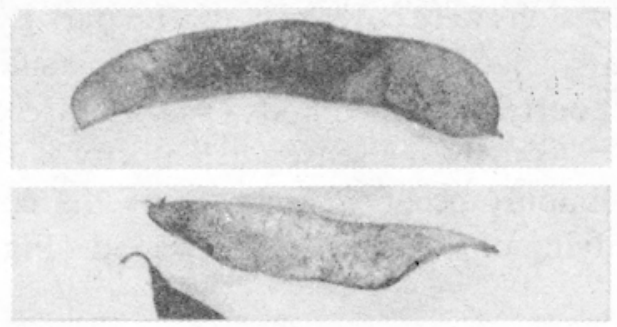

Fig. 5. Pycnidia of Ascochyta sojaecola on soybean pods

Sclerotinia stem rot caused by Sclerotinia sclerotiorum was reported only from some fields $\langle$ Table 1$\rangle$. The fungus commonly attacked the lower part of the stem which became soon rotten. Brownish lesions were covered next with cottony whitish mycelium encrusted with black sclerotia $\langle$ Fig. 6$\rangle$. Soybean plants were killed prematurely as the results of infection.

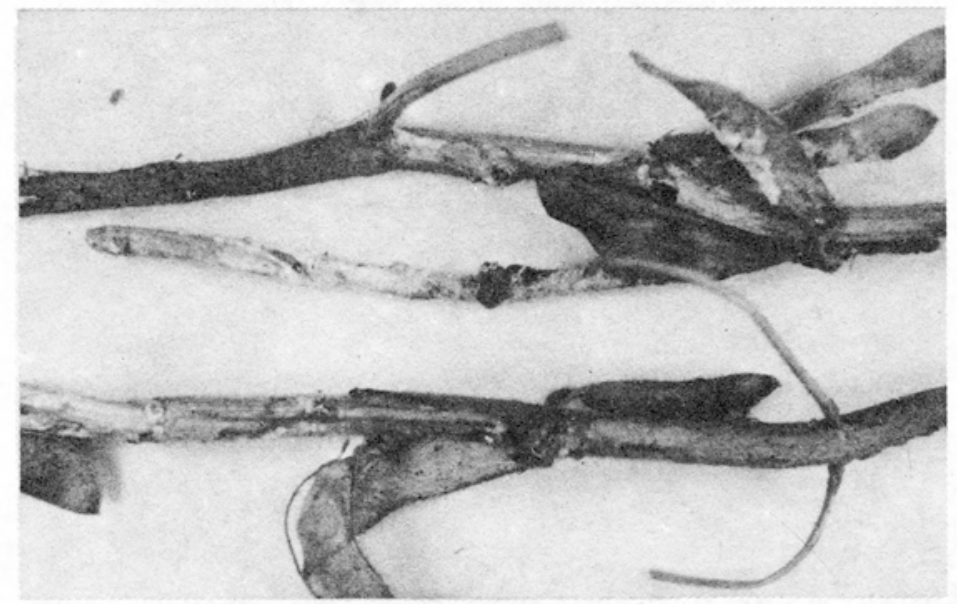

Fig. 6. Sclerotinia stem rot on soybean pods and stems

Botrytis cinerea the causal fungus of gray mold was locally noted usually on soybean stems in wet seasons on a high density plantation. The fungus especially affected plants in the maturity period.

Bacterial blight symptoms appeared first on cotyledons. Then, depending on an air moisture Pseudomonas syringae pv. glycinea could be at once carried onto the developing leaves or the bacteria were able to survive on cotyledons. Spots on leaves first small, yellow, angular, watersoaked soon became brown $\langle$ Fig. 7$\rangle$. The 
spots frequently conglomerated and necrotic tissue dropped or was torn away giving the leaves a ragged appearance $\langle$ Fig. 8$\rangle$. Similar spots and also dark brown streaks appeared on pods $\langle$ Fig. 9$\rangle$. Bacterial blight of soybean of different intensity was noted even in the same region according to the air humidity and temperature $\langle$ Table 2$\rangle$.

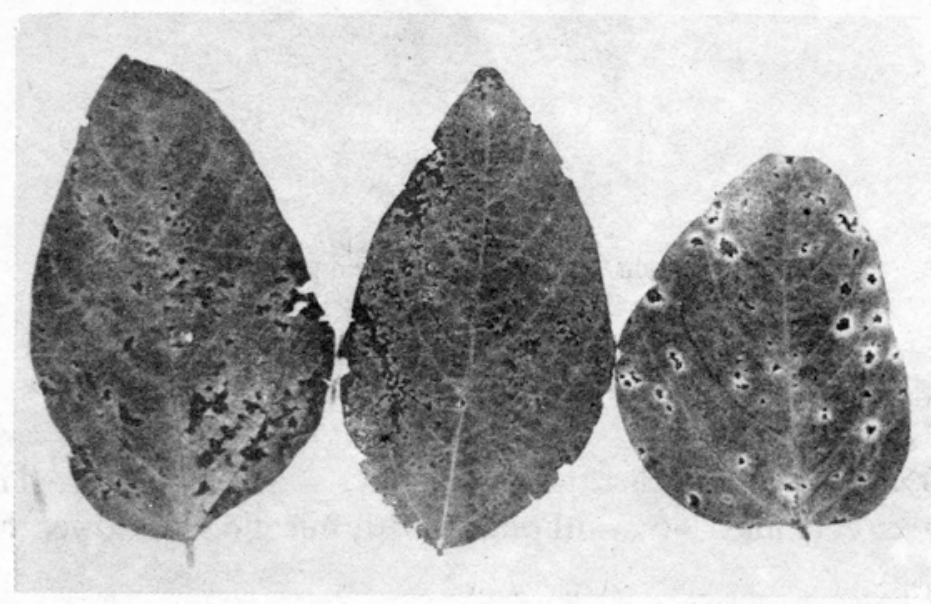

Fig. 7. Symptoms of bacterial blight on soybean leaves

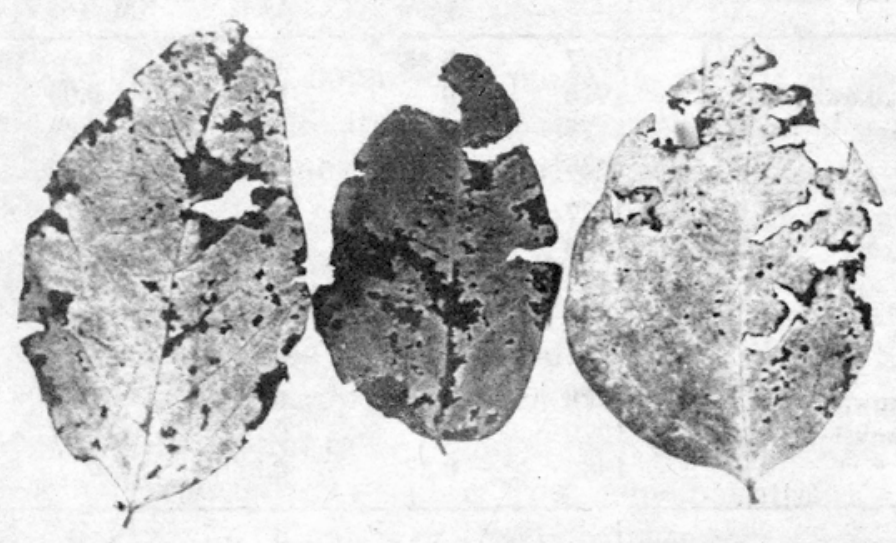

Fig. 8. Effect of infection by Pseudomonas glycinea on soybean leaves 


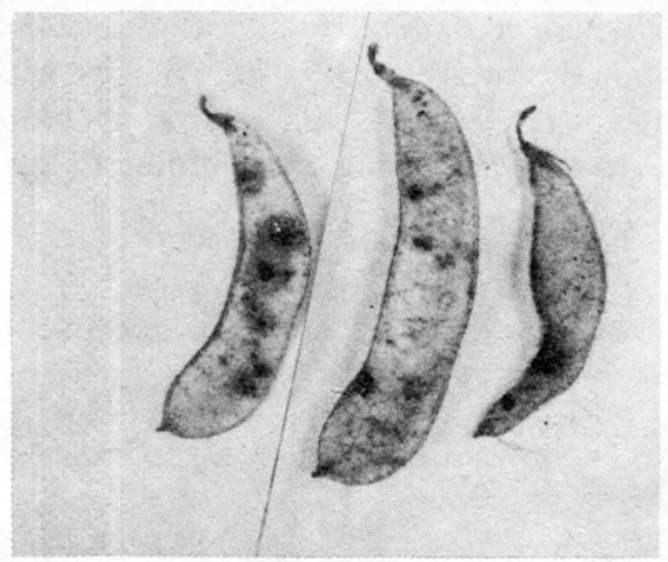

Fig. 9. Symptoms of bacterial blight on soybean pods

Of soybean virus diseases only soybean mosaic caused by SMV was found in Poland. This disease was common everywhere but its incidence was always very low $\langle$ Table 3$\rangle$. During four years the tested varieties and lines showed infection, ranging between zero and $5.45 \%$, although mostly infection was lower than $1 \%$ of infected plants.

Table 3

Soybean infection by soybean mosaic virus during 1977-1980 (per cent of infected plants)

\begin{tabular}{|c|c|c|c|c|}
\hline \multirow{2}{*}{$\begin{array}{l}\text { Location } \\
\text { and district }\end{array}$} & \multirow{2}{*}{ Year } & \multicolumn{3}{|c|}{ Varieties and line } \\
\hline & & Acme & Ajma & $N M-4855$ \\
\hline $\begin{array}{l}\text { Radzikठw } \\
\text { Warsaw }\end{array}$ & $\begin{array}{l}1977 \\
1978 \\
1979 \\
1980\end{array}$ & $\begin{array}{l}5.45 \\
0 \\
0.44 \\
0.16\end{array}$ & $\begin{array}{l}2.69 \\
0.03 \\
0.17 \\
0.34\end{array}$ & $\begin{array}{l}0 \\
0.03 \\
0.09 \\
0.08\end{array}$ \\
\hline $\begin{array}{l}\text { Przechaw } \\
\text { Rzeszów }\end{array}$ & $\begin{array}{l}1977 \\
1978 \\
1979 \\
1980\end{array}$ & $\begin{array}{l}-\overline{12} \\
0.16 \\
0.20\end{array}$ & $\begin{array}{l}0.33 \\
0.12 \\
0.37 \\
0.12\end{array}$ & $\begin{array}{l}1.75 \\
0.03 \\
0.1 \\
0.16\end{array}$ \\
\hline $\begin{array}{l}\text { Jankowice } \\
\text { Przemyśl }\end{array}$ & $\begin{array}{l}1977 \\
1978 \\
1979 \\
1980\end{array}$ & $\begin{array}{l}0.5 \\
0.08 \\
0 \\
0.37\end{array}$ & $\begin{array}{l}0.45 \\
0.08 \\
0.07 \\
0.37\end{array}$ & $\begin{array}{l}0.1 \\
0.06 \\
0.07 \\
0\end{array}$ \\
\hline
\end{tabular}

Disease symptoms, which occurred in the field $\langle$ Fig. 10〉, were similar to typical symptoms produced by SMV. The leaves of diseased plants were mottled, puckered, distorted, asymmetric, stunted and often curled downwards at the 
margins. Some diseased plants were stunted with shortened petioles and internodes. Generally a reduction in the number and size of pods and seeds occurred. Some infected plants produced seeds with mottled seed coats. As maturity approached, the leaves of infected plants remained greener longer than those of healthy plants. Mosaic symptoms were best seen during the blooming stage of soybean. In Poland this period is recorded from the end of June to the beginning of August.

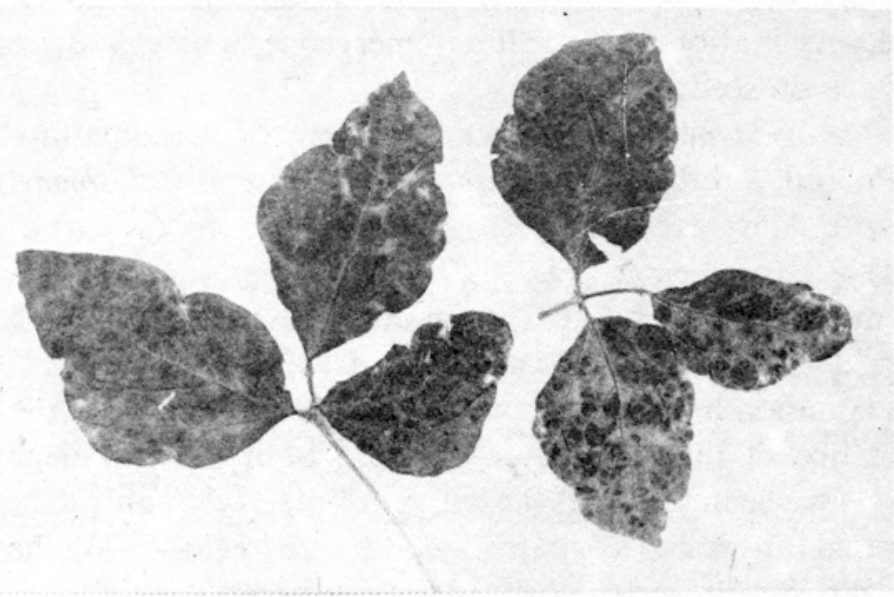

Fig.10. Symptoms of soybean mosaic on leaves

\section{DISCUSSION}

In Poland like in the other countries of moderate climate, characterized by heavy rainfalls, most prevalent are foliage diseases such as downy mildew, bacterial blight and soybean mosaic 〈Hilde brand, 1948; Mikhailenko, $1965\rangle$. Diseases characteristic for intensive soybean plantations were mostly caused by soil pathogens like Phytophthora magasperma f. sp. glycinea Kuan and Erwin, Rhizoctonia solani Keuhn, Cephalosporium gregatum Allin. and Chamberl., Macrophomina phaseolina 〈Tassi〉 Goid 〈Sinclair and Shurtleff, $1975\rangle$. Since soybean is a new crop in our country, so far grown on a small area, the soil pathogens do not seem to be of any importance for a long time.

Ascochyta blight reported very seldom from some countries $\langle\mathrm{A} \mathrm{bra} \mathrm{mov}$, 1931; F r a n d s e n, 1953; T o th and K ovi cs, 1978> was widespread on soybean in Poland. Nevertheless, this disease was not so dangerous as downy mildew because Ascochyta sojaecola attacked older, maturing plants. On the other hand, downy mildew seems to be an important disease on soybean since Peronospora 
manshurica appeared on young plants and usually with high intensity. The two former diseases could be treated as common, while sclerotinia stem rot was a typically local disease. Sclerotinia sclerotiorum was a fungus of wide host-range plants and survived in the soil over the next seasons, thus the forecrop determined the soybean damage and yield losses. One of the widespread fungi causing soybean pod and stem blight has been Phomopsis sojae Leh. The disease was of economic value in the United States of America $\langle\mathrm{Kmetz}$ et al., 1978; Hepperly and Sinclair, 1978 $\rangle$, Brazil $\langle$ Bolk a n et al., 1976 $\rangle$ and Soviet Union $\langle$ Zhukovskaya, 1977〉. In these regions the pathogen commonly reduced seed germination and seedling emergence, whereas in Poland it was found only once on seeds.

Pseudomonas syringae pv. glycinea was the only bacterial pathogen noted on soybean in Poland, another one Xanthomonas phaseoli var. sojensis 〈Hedges〉 Starr and Burkholder developed best in warmer regions $\langle\mathrm{K} \mathrm{h}$ a re et al, 1971; Pola n c o, 1974; B aka eva, 1975>.

Soybean mosaic caused by SMV as in other countries <M u rav'e va, 1969; Mura y m a and Ha n, 1971; Si g noret et al., 1976; I r win and Good ma n, $1980>$ is also common in Poland but its incidence is low. One of the reasons for the low incidence of this disease could have been the low degree of SMV transmission by soybean seeds. It was found in Poland that only $0.2 \%$ of soybean seeds transmitted this virus. In Japan $\langle\mathrm{T}$ a $\mathrm{k}$ a h a s $\mathrm{i}$ et al., 1974 $\rangle$ the rate of seed transmission varied from zero to $76 \%$. In the southern United States $\langle\mathrm{De} \mathrm{m} \mathrm{s} \mathrm{ki}$ and $\mathrm{Harris}, 1974>$ seed transmission was found to be only $1 \%$ or less. The percentage of virus-infected seeds to a large extent determines the incidence of soybean mosaic, because systemically infected plants which arise from infected seeds are a primary source of infection.

Because SMV is found everywhere and it is transmitted by soybean seeds, easily in a nonpersistent manner by aphids and mechanically by sap, so soybean mosaic may become a dangerous soybean virus disease in Poland.

In the future with an increased area of cultivation there may appear within the country other soybean diseases of economic importance.

\section{REFERENCES}

A bramov I. N., 1931. Fungal diseases of soybeans in the Far East. Vladivostok 120 pp.

Acimovic M., 1976. Osetljivost novog sortimenta soje prema Peronospora manshurica. Zastita

Bilja 27: 289-293.

A rx von J. A., 1974. The genera of fungi sporulating in pure culture. J. Cramer $315 \mathrm{pp}$.

B a k a e v E. V., 1975. Some biological characteristics of the pathogens of bacterioses of soybean in the Alma-Ata district. Vestnik Selskokhozyaistvennoi Nauki Kazakhstana 10:48-52. Rev. Appl. Mycol. 55: 3372. 
Bolk a n H. A., de Silva A. R., Cupertino F. P., 1976. Fungi associated with soybean and bean seeds and their control in Central Brazil. Plant Dis. Reptr. 60: 545-548.

B o oth C., 1971. The genus Fusarium. Com. Myc. Inst., Kew, Surrey 237. pp.

Daft G. C., Le ben C., 1972. Bacterial blight of soybeans: epidemiology of blight outbreaks. Phytopath. 62: 57-62.

De msk i J. W., Harri is H. B., 1974. Seed transmission of viruses of soybean. Crop Sci. 14: 888-890.

D u n l e a v J. M., 1971. Races of Peronospora manshurica in the United States. Amer. J. Bot. 58: 209-211 .

Frandsen N. O., 1953. Ascochyta sojaecola auf Sojabohne in Deutschland. Phytopath. Z. 20: 375-382.

Gardner M. W., Kendrick J. B., 1921. Soybean mosaic. J. Agr. Res. 22: 111-117.

Gä u ma n n E., 1923. Beitrage zu einer Monographie der Gattung Peronospora Corda. Zürich. Ed.

Gebr. Fretz A. G., 360 pp.

Hepperly P. R., Sinclair J. B., 1978. Quality losses of Phomopsis-infected soybean seeds. Phytopath. 68: 1684-1687.

Hild e br and A. A., 1948. Soybean diseases in Ontario. Soybean Dig. 8: 16-17. Rev. Appl. Mycol. 28, 154.

Hilde bra nd A. A., K och L. W., 1951. A study of systemic infection of downy mildew of soybean with special reference to symptology, economic significance and control. Sci. Agric. 31: 505-518.

Hu le a A., R os ca I., B un escu S., 1973. Ciuperci patogene pe soia semnalate recent in Romania. Probleme de Protecia Plantelor 1: 177-190.

I rw in M. E., Goodman R. M., 1980. Ecology and control of soybean mosaic virus. INTSOY, Univ. Illinois, Urbana, $67 \mathrm{pp}$.

K a d o C. I., H e sk e t t M. G., 1970. Selective media for isolation of Agrobacterium, Corynebacterium, Erwinia, Pseudomonas and Xanthomonas. Phytopath. 60: 969-976.

Khare M. K., Sharma H. C., Kulkarni S. N., Chand T. N., 1971. Bacterial pustule of soybeans - varietal resistance under field conditions. Mysore J. Agric. Sci. 5: 123-126. Rev. PI. Path. 51, 2650.

K1y k ov A. P., 1963. Bacterial diseases of soybean. Zashch. Rast. 8: 35-36. Rev. Appl. Mycol. 42: 625.

K metz K. T., Schmitthenner A. F., Ellet t C. W., 1978. Soybean seed decay: prevalence of infection and symptom expression caused by Phomopsis sp., Diaporthe phaseolorum var. sojae and D. phaseolorum var. caulivora. Phytopath. 68: 836-840.

Lelli ott R. A., Billing E., Hayward A. C., 1966. A determinative scheme for the fluorescent plant pathogenic pseudomonads. J. Appl. Bacteriol. 29: 470-489.

Mikhailenk o A., 1965. Diseases of legumes in the Primorsk region. Zashch. Rast. Vredit. Bolez. 10: 41-43. Rev. Pl. Path. 44: 2928.

M u rav'eva M. F., 1968. Virus diseases of soybean. Abs. in Referat. Zhurnal〈Rasten〉12, 993. Rev. Appl. Mycol: 48: 992.

Murav'eva M. F., 1969. Soybean mosaic. Zashch. Rast. Mosk. 14: 18-19. Rev. Pl. Path. 49: 1219.

M u ra y a ma D., Han Y. H., 1971. Occurrence of soybean mosaic virus in Taiwan. Plant Prot. Bull. 13: $75-86$.

Pola n co C. D., 1974. La pustula bacteriana de la soya en Venezuela. Agronomia Tropical 24: 279. $-287$.

Purdy L. H., 1955. A broader concept of the species Sclerotinia sclerotiorum based on variability. Phytopath. 45: 421-427.

R os c a I., 1975. Aspects of losses caused by Peronospora manshurica in soybean crops in Rumania. Probleme de Protectia Plantelor 3: 101-109. Rev. Pl. Path. 56: 1832.

Sign ore t P. A., Poin so B., B ern a ux P. C., 1976. Les maladies du soja en France. Agric. Consp. Scient. 39: 459-464.

Sinclair J. B., Shurtleff M. C., 1975. Compendium of soybean diseases. Amer. Phytopathol. Soc., St. Paul, Minnesota 69 pp. 
Takahashi K., Tanaka T., Tsuda Y., 1974. Soybean mild mosaic virus. Ann. Phytopath. Soc. Japan 40: 103-105.

Toth O., Kovics G., 1978. Az Ascochyta sojaecola Abramov szoja korokozo Magyaroraszagi megjelenese. Novenyvedelem 14: 290-304.

Zhu k ovsk a y a S. A., 1977. Kornevye gnili soi v Primorskom Krae. Mikol. Fitopat. 11: 140-144. $\mathrm{Zw}$ a tz B., 1979. bacterial leaf spot disease of soybean. Pflanzenarzt, 32: 96-97.

\section{Występowanie chorób soi w Polsce}

\section{Streszczenie}

Występowanie chorób soi obserwowano na poletkach doświadczalnych oraz na uprawach produkcyjnych w centralnej i południowej części Polski w latach 1976-1980. Mączniak rzekomy powodowany przez grzyb Peronospora manshurica, bakteryjna plamistość wywoływana przez Pseudomonas syringae pv. glycinea oraz mozaika soi 〈wirus mozaiki soi - SMV〉 zostały uznane za najważniejsze choroby soi ze względu na powszechność ich występowania i łatwość rozprzestrzeniania. Nasilenie rozwoju tych chorób liściowych różniło się w kolejnych latach zależnie od rejonu uprawy soi i jej odmiany. Bakteryjna plamistość i mozaika soi występowały w większości badanych obiektów. Mączniak rzekomy był mniej powszechny, tym niemniej obserwowano zarówno silne jak i słabe porażenie upraw soi przez Peronospora manshurica. Podobnie zróżnicowane porażenie roślin soi występowało w przypadku bakterii Pseudomonas syringae pv. glycinea. Stwierdzono male nasilenie SMV. Askochytoza soi powodowana przez Ascochyta sojaecola, chociaż występowała powszechnie, miała mniejsze znaczenie, ponieważ pojawiała się na dojrzewających słabszych roślinach, natomiast grzyb Sclerotinia sclerotiorum, który powodował placowe zamierania roślin, był lokalnie groźnym patogenem soi. Sporadycznie obserwowano występowanie Botrytis cinerea, Fusarium culmorum i Furarium oxysporum oraz Rhizoctonia solani. 